\title{
Between the Barrio and the City: Pathways of Work among Scavenging Families
}

\author{
Débora Gorbán \\ Conicet/Idaes-Unsam, Buenos Aires, Argentina \\ Email: dgorban@gmail.com
}

Received 3 November 2013; revised 7 December 2013; accepted 16 December 2013

Copyright (C) 2014 by author and Scientific Research Publishing Inc.

This work is licensed under the Creative Commons Attribution International License (CC BY). http://creativecommons.org/licenses/by/4.0/

(c) (i) Open Access

\begin{abstract}
In this article, I will reconstruct, through brief stories, some of the traits that characterize the way of life of families in the El Salvador neighborhood, in Buenos Aires, Argentina, go scavenging everyday in Buenos Aires city. These stories will not only tell us who they are and how they arrived at the El Salvador neighborhood, from where, and in what manner they began to salir con la carreta, but will also permit us to move closer to the day-to-day existence of these families in relationship to their life in the barrio and the activities they engage in, thereby giving us a fuller understanding of family dynamics. In the research that originated this paper, I followed an ethnographical perspective to study and analyze the way of life of those families living from the recyclable waste they recollect in Buenos Aires city.
\end{abstract}

\section{Keywords}

Cardboard Pickers; Labour; Poverty; Recycalable Waste; Buenos Aires

\section{Introduction: The Beginnings of a Journey}

One afternoon in October of 2002, I arrived at the train station in the northern zone of the city of Buenos Aires in search of the women and men who, along with their families, take the train into the city to collect paper and cardboard. My curiosity had been piqued far from these streets, in a barrio typical of Buenos Aires located a few blocks from the Plaza de Mayo. A few months earlier, as part of another investigation, I had attended one of the many marches that the "organizations of the unoccupied/unemployed" held demanding employment. I found myself in the midst of a crowd of men, women and youth that were moving along Avenida de Mayo towards the plaza. Some of the youth were playing drums, while women marched with their babies in their arms, some girls were part of the group in charge of security. Suddenly in the midst of the commotion, a 30-something year old man literally crossed through the march. This man was pushing a wagon made out of pipes and pieces of canvas 
which held some dismantled cardboard boxes. The man kept walking without stopping as he passed through the marchers. The image of this man crossing from one side of the protest to the other puzzled me. In a mobilized society, particularly given the renewed momentum within the popular sectors, the presence of this lone man crossing a march demanding work turned my attention to those who, though part of the same social sector, found themselves at the margins of mobilization. A year had not yet passed since the events of December 2001, and in this context where research of "picketing" organizations and "recovered factories" (among other forms of social organization) abounded, I arrived at the train station asking myself why these men and women who gathered paper and cardboard in the street were not marching alongside the picketers. In a moment of seemingly "permanent mobilization," one of society's least favored groups began to make itself "visible". Not in marches, pickets, factory takeovers or other forms of protest, but instead through their silent daily journey through the streets of a city that seemed to offer them only its rubbish.

Seeking to understand their lifestyle, I constructed my investigation around their circulation between the city, the train, and the barrio. Starting with my first encounter with the cartoneros $^{1}$ and their carts in the city, I headed for the railway station. From the station, I took the train to visit their neighborhoods, their houses, the spaces where one part of their daily lives unfolded, and from there I returned with them to the city. Thus, in countless trips between José León Suárez and the Capital, I learned that the practices of these families are not anchored solely in the barrio but also find part of their territoriality in the city. During 6 years of fieldwork, I traveled from the city to the barrio, and back to the city, sometimes alone, and many times with some of the women who became "informants" and to whom I developed a certain attachment.

When I began my fieldwork, one of the questions I kept asking myself was: why did these people become cartoneros $^{2}$ ? What motivated them to salir con la carreta (leave the neighborhood and go scavenging)? ${ }^{3}$ Why did they not look for another alternative? As my work continued, these questions evolved, acquiring a new significance in my research. To answer them would depend on the life story of each of the people I met during those years. In their stories, their beginnings appeared to be linked to distinct moments, and sometimes did not appear like a beginning at all, but rather like part of a process, or a path. I began to realize that the question could not begin with assumptions related to their material conditions (poverty) ${ }^{4}$, but rather should be oriented toward understanding how a group within the urban popular sector was constructing, through a specific practice, a lifestyle of their own.

In an earlier work [1], my curiosity about the recollection process and the people involved was related to the deterioration of the labor market; this time I was interested in understanding the daily circumstances, the worlds of meaning of these people as reflected in the daily manifestations of this practice.

In this article, I will reconstruct, through brief stories, some of the traits that characterize the way of life of families in the El Salvador neighborhood that go scavenging everyday in the Capital. These stories will not only tell us who they are and how they arrived at the El Salvador neighborhood, from where, and in what manner they began to salir con la carreta, but will also permit us to move closer to the day-to-day existence of these families in relationship to their life in the barrio and the activities they engage in, thereby giving us a fuller understanding of family dynamics.

These reports and stories, reconstructed from numerous interviews, meetings, and informal conversations that took place during my fieldwork, are not isolated from one another but interconnected, delineating a dense web of relationships of which they are a part. And it is within this web that the practice of collection is situated. Moving from the city to the barrio, from some of the houses to those who I had met in the city, this web of relationships and exchanges unfolded for me. Without them, la salida could not be understood.

\section{A Journey through the Barrio "El Salvador"}

This research focuses on a segment of the population that lives on the outskirts of Buenos Aires in an area con-

\footnotetext{
${ }^{1}$ This is the name given to people who dedicated themselves to the collection and sale of recyclables such as paper, cardboard, glass, or plastic. For a detailed analysis about the forms of naming those dedicated to these kinds of tasks in Argentina, consult [2].

${ }^{2}$ Italics will be utilized to emphasize significant categories and expressions in the symbolic universe of the social group under analysis, quotation marks and italics represent testimonies or extracts from them; quotation marks reference categories attributed by others, while single quotations denote author emphasis.

${ }^{3}$ Residents of the barrio to refer to going out to collect recyclable materials use the local expression "salir con la carreta". In the pages that follow I will explore the ways in which this expression is understood.

${ }^{4}$ On this point I follow [3] who cautions against emphasizing the negative aspects of the group under study in search of a political effect of the investigation.
} 
centrated with poor neighborhoods characterized by bad living conditions but that distinguishes itself from "other poor people" by the possession of a house.

The barrio El Salvador is located in José León Suárez, an area in the northern zone of Greater Buenos Aires. The "barrio," as its inhabitants know it, is one of the many "shantytowns" that we encounter traveling through what is known as Área Reconquista, in San Martín district. This land is characterized by high levels of environmental contamination (industrial waste, flooding, hidden dumps). The barrio is approximately twelve blocks long and six wide, between Avenue Márquez to the east and Camino del Buen Ayre to the west. Extending outward to its right lies a former textile factory, and to its left, a property occupied by a church and its school. The fastest route to the barrio from Buenos Aires is via the former Mitre railway, to the José León Suárez station. From the station, you can walk one houndred meters to San Martín street, its border to the north, or via San Benito Street, which is perpendicular to Avenue Márquez and borders the industrial property located in a large lot in front of the barrio. Another way to get there is via car services that make the trip between the station and the barrio, following the Avenue San Benito to enter the lot.

Running these car services ${ }^{6}$ is one of the major sources of income for many of the men in the barrio, who drive old vehicles with rickety doors, dented and badly patched up bodies, and chipped paint. Neighboring barrios rely on them as a principal means of transportation in order to get to the center of San Martín, to take merchandise to the barrio, or to go to the hospital. This car services are requested in one of the numerous car services offices found in the barrio, or in the train station of José León Suárez, where more than once I took one to get to El Salvador.

The trip from the train station to the barrio takes about five minutes and costs 3 pesos (less than 1 dollar). In my visits, I get there via car service along San Benito Street, and returned to the station walking down San Martín to catch the train back to the Capital. It took me a year of visits to the barrio to understand that the street San Benito, in addition to being the principal access point, was the border between the older part of the barrio (commonly identified as El Salvador), and the other, more recent (alternatively known as Curita or El Salvador). For the unobservant visitor, these two barrios appear to be one. However, as we enter the stories of their inhabitants, two distinct territorial configurations begin to emerge: to the left of this street extends the land where the first inhabitants built their houses, the great majority of whom came from the provinces of Santa Fe, Tucumán, Corrientes, as well as neighboring countries like Paraguay.

Advancing along this street the pavement becomes increasingly precarious until it turns to a dirt road; the lateral streets begin to narrow, becoming alleyways that open up to the left and right four hundred meters further into the neighborhood. To go beyond the first group of buildings in the barrio requires walking down these alleys, which meander between the houses, passing by a center of several blocks and connecting the dirt roads with one another. To return to the metaphor of the border, San Benito Street separates the new and old parts of the barrio, making evident the segmentation between them. However, this segmentation is not obvious until one passes over the border, entering the pathways on either side. Once on the other side of the street-border in direction to the older part of the neighborhood, we can observe the wideness of the streets, the spacious lots, greater vegetation, all of which contrasts with the reticular network of narrow alleys on the Curita side. Here the houses, though no less precarious, are closer to one another; on both sides there are also a variety of materials, cartons, plates, and other items. Sometimes you can tell the age of a house by the type of construction; the houses of those with a longer history of residence tend to be sturdier. Before El Salvador expanded into what is now Curita, some of its residents remember that there was nothing there except "fields and some cows". The land had no buildings of any kind. The barrio expanded as many of the children and relatives of those living in El Salvador began to build houses in the open countryside.

However, despite the aforementioned differences, the residents themselves who live in El Salvador and Curita do not always refer to them as separate barrios. In the first interviews that I did with its inhabitants, as well as members of other barrios in the area, there did not seem to be any pattern to the use of either name. The barrio was simply introduced as El Salvador or Curita. Inquiring into the meaning of the vague usage of names resulted in responses like "some say one thing, others say another."

\footnotetext{
${ }^{5}$ I refer to men, women, and children without a roof. As investigations about these populations show, the street-both refuge and place of sustenance - is determinant in their organizational dynamics. For a meticulous analysis about children on the street see [4]; about "homeless in San Francisco, [5], and for an ethnography about "moradores de rua" (street dwellers) in Puerto Alegre, consult [6].

${ }^{6}$ They are called "remises (car services) truchos" because they are not officially registered as passenger vehicles, lack licenses, and do not meet the security standards of the motor vehicle registry.
} 
Behind the barrio there is a view of a green hill, where seagulls fly overhead. From a distance this hill might be confused with an innocent park. In fact, it is a landfill of the CEAMSE (Coordinación Ecológica Ambiental Sociedad del Estado ${ }^{7}$ ). The locals call this place la quema, which refers to the mountain of trash that accumulates daily in the landfill following the unloading of trash collection trucks from various municipalities in and around the city of Buenos Aires. There, men, women, and children enter for one hour (the time allowed by the CEAMSE authorities), under the supervision of the security guards, to collect trash. For many in El Salvador and other nearby settlements, la quema is a source of sustenance. They walk forty minutes to the landfill, where, if the guards let them, they have one hour to look through the garbage for anything from food to recyclables. This practice of recollection in la quema is in addition to the cartoneo (scavenging) one of the only forms of recycling household refuses done in Buenos Aires ${ }^{8}$.

In contrast to the route to the quema, which is reached on foot or by bike, the trip to the Capital is by train ${ }^{9}$, a journey of approximately 35 minutes which connects some of the humblest barrios of the northern region of Greater Buenos Aires with one of the wealthiest residential areas of the city. It is there, in the streets of neighborhoods like Belgrano, Coghlan, Palermo, where the wagons that are used to carry collected items, descend. These neighborhoods are predominantly characterized by luxurious buildings, towers, single-family houses located on tree-lined streets, next to the most fashionable streets, where the property value of one square meter is one of the highest in town. Located in this same area are various commercial centers, oriented toward middle-upper class consumers. The trip by train from José León Suárez to Palermo neighborhood allows one to observe the transformation of the urban landscape, from the lowest social sectors of San Martín to the highest in the Capital. As the train heads into the city, it passes Villa Pueyrredón station, then Gral. Urquiza, Luis M. Drago, Belgrano R, Colegiales, Ministro Carranza, 3 de Febrero, finally arriving at the Retiro terminal, thereby traversing the middle class barrios towards those which are middle-upper class, as it moves from the periphery toward the center of the city ${ }^{10}$. The train links two geographically and socially distant areas that are traversed daily by many inhabitants of El Salvador and other poor barrios of the José León Suárez area when they leave to scavenge $e^{11}$ and beg $^{12}$.

It is important to emphasize that from 1950 until the beginning of the 1970s the San Martín district in the province of Buenos Aires where El Salvador is located, was one of the most highly industrialized zones of the province. Many men and women sought employment in the textile mills and metalworking factories there. During this period, middle class barrios in José León Suárez as well as other localities in the area expanded. Many workers in the small industrial plants built their homes there, establishing a territory full of Italian, Spanish, and German immigrants who came to work in the said industries. Many of these workers (nationals or immigrants) built their homes in these areas because of the ease with which they could acquire land, many times with credit; later they built their houses with their own hands or with the help of their families. A large number of these industrial workers were still based in the Federal Capital, where housing costs or rents were virtually inaccessible for them.

At the same time, some shantytowns ${ }^{13}$ began to grow around these neighborhoods, home to other workers perhaps with less qualifications or a lower position in the production chain, and therefore less resources, recently arrived from other provinces. In that moment, makeshift dwellings were built with the idea that they would be

\footnotetext{
${ }^{7}$ For an analysis of the distinct ways of operating and depositing solid waste in the city of Buenos Aires, see [1].

${ }^{8}$ For two years, I visited a settlement also located in San Martín. This one was located forty blocks (fifteen minutes by public transportation) from the barrio El Salvador. However, this distance affected the strategies employed by its inhabitants in their search for resources. Among these, the "salidas a cartonear" did not appear to be a popular option like in El Salvador. Being located far from the train station, they would have to walk about an hour with the cart, or pay for a ticket (where they could not take a cart) to take the train. While in El Salvador the daily movement included carts and trips to the city, in this settlement, the most common practice among its inhabitants was "to go to la quema".

${ }^{9}$ I refer to the "Tren Blanco", a rail service that operated from 2000 until late December 2007, transporting passengers between José León Suarez and the Federal Capital. This service was exclusively for cartoneros, and charged only a nominal fee. Like other train services that unite the northern zone with the city of Buenos Aires, it was run by the company Trenes de Buenos Aires (TBA).

${ }^{10}$ The train trip between José León Suárez and the city of Ciudad de Buenos Aires can be read as a traversing of geographic and social borders. However, this perception of borders will be by the heavy circulation between barrio and city that develops/forms who scavenge.

${ }^{11}$ Salir a cartonear.

${ }^{12}$ Pedir.

${ }^{13}$ The shantytowns and squatter settlements constitute ways of occupying urban space developed by the poorest sectors denied or lacking the possibility of a house. The shantytowns were largely constructed and inhabited by rural migrants that arrived searching for work, a migratory process that intensified around 1940. The physiognomy of these spaces is generally described as an intricate network of alleys and some dirt streets, where houses are erected using all kinds of materials such as cardboard, wood, even brick and cal. An absence of urban "design" and unplanned growth are characteristic of the shantytowns. The squatter settlements emerge as a consequence of the urban policy of the military dictatorship - mid-1970s and 1980 — and the lack of alternatives for low-income families. These occupations seek to differentiate themselves from the villas by adhering to urban design rules in their physical planning [10].
} 
rapidly abandoned for better homes; this goal was realized by many, but became much more difficult over time. In the 1970s, a large percentage of the factories and businesses of the area, which had developed under the import substitution model [7], closed their doors or reduced their operations in response to the economic policies of the 1970 s and onward ${ }^{14}$.

After the decade of the 1990s, the "integrated myth of indefinite progress" [8] appeared to be permanently banished from the collective imagination. In this sense, it appears as if the process of social structural transformation have ended in a process of "social polarization" in which the working class diminished while the numbers of "excluded" increased. But we believe that this kind of analysis of the social structure transformation might lead to a series of dichotomous representations of the social world that could hide the historical particularities of this social process. We sustained that in this process the ways in which the working classes relate to work are modified, so in this sense these transformations suppose a change in the historical inscription of working classes that is not produced homogeneously. It is therefore necessary, in order to capture the different ways in which this relation to work changes, to consider the existing specificities in the symbolic matrices of subaltern groups, a task that the ethnographic method makes possible [9]. Is in this sense, the significant social process that working classes are experiencing in the last thirty years such as the prevalence of a territorial logic, the weakening of traditional forms of work, and the erosion and reconfiguration of certain political ties do not acquire always the same form nor do they combine in the same way in each case.

The practice of scavenging becomes part of this same process by which working classes daily life is reorganized, modifying the way its participants relate to the world around them. Former workers had to recognized themselves as "cartoneros" behind a wagon. This new situation is not only about being unemployed but also about how this lost job leads to a reconfiguration of everyday life where the wagon and the daily trip to the city replaced the factory. In this new experience, work, family, and politics are articulated and intertwined in different and originals forms.

The stories reconstructed in the pages that follow demonstrate how agents traverse and sometimes burst the classifications that polarize the social world. They allow us to illuminate a crucial aspect of the way of life of those dedicated to cartoneo. The life project of the families studied here cannot be understood without being situated in the symbolic web of the familial group where they inscribed themselves. This will let us focus on the study of the way in which individual and family articulate together, articulation where individual and family projects become blurred. Thus forcing us to turn our eyes to the broader family ties that define them.

So the continuities and discontinuities in the pathways we reconstruct in this paper will reflect the completion of a series of moral obligations tightly linked to the social role of the individual in the group. This will also lead us to analyze and put into question the boundaries between labour and cartoneo. That is to say that we have to situate these practices in the web of reciprocation where these families belong. In that sense the interruptions in individuals trajectories' have to be understood as part of a familial strategy in the search for resources. Is from this point of view that we would be able to comprehend the pairs individual/family and labour/cartoneo not as dichotomous but as complementary, or even more as transitional pairs between which there are no theoretical boundaries.

\section{Stories with History}

One of the questions I asked repeatedly to the men and women that I encountered on the city streets with wagons was why they dedicated themselves to this activity, and what did they did before scavenging. I was interested in reconstructing the trajectories of these people who I saw every afternoon in the center of town, in different neighborhoods, sorting and selecting refuse. In this moment, post-2001, the "crisis" and its consequences motivated a large number of studies in the social science field ([17] [18] among others). The idea percolating in my reflections was that these trajectories could be grouped together and attributed to poverty and unemployment. According to this line of thinking, it was the lack of work that had led these men and women to salir con la carreta.

This was my point of departure, a supposition that in the beginning acted as a veil that prevented me from seeing beyond it. Through years of conversations and shared trips with some of these cartoneros, I realized that

\footnotetext{
${ }^{14}$ It is not the objective of this work to conduct a detailed analysis of the structural transformation in recent Argentine history; for more on this topic, consult Azpiazu and Schorr [11]; Basualdo [12], among others. For more on the transformation of the labor market in Argentina see Battistini [13]; Altimir and Beccaria, [14]; Salvia [15] [16], among others.
} 
it was not about reconstructing trajectories of a supposed "lack", a direct consequence of unemployment. Rather, it required setting aside a normative vision that could lead me dangerously close to reifying these subjects, imposing sociological categories and ignoring those which are part of the world that we try to understand. Moving forward implied denaturalizing these explanations in order to be attentive to the daily experience of these people, and the distinct ways in which meanings and practices are intertwined.

\subsection{Spatial Symbols}

In the distinct interviews and conversations that I held with the inhabitants of El Salvador, the barrio appears as a place that people "enter" and "leave", that possesses an "inside" and an "outside" that delineates the border between this space and its surroundings. At the same time, these borders operate like markers that distinguish and symbolize the barrio, and account for how this "inside" is perceived. Accordingly, the barrio appears to be a well-defined space entered through specific access points (the "zanjón" (ditch) street or San Benito, in the barrio El Salvador, and the asphalt road, "la del jardín" (garden street) or "la que baja" (slope street), in the case of La Esperanza, the neighboring barrio). The level of difficulty involved in entering and leaving depends on the person-whether he or she is a resident or from another place. Such actions refer on the one hand to the movement required to get to the barrio or to leave from there to get to other places -the Capital, the municipality, the avenue-where people go to shop, travel, or work. In this sense one of the expressions most frequently used by the residents of both barrios is "salir a cartonear ${ }^{15}$ ", which sums up the experience of the practice of collection and the link between the barrio and the Capital. Many times the expression is used in its abbreviated form salir (to leave), without an explicit reference to where or what.

In this way, to work it is necessary to leave the barrio to go to the city in search of resources to subsist. From the barrio "one leaves" to "go to the Capital", where you obtain what is necessary to live - whether through "the wagon", that is, the recuperation of refuse, or "to beg", or in some cases "to steal", the city is seen as a center of abundance. A variety of resources are found there: what they collect on the street, what neighbors and doorkeepers separate and save for then; merchandise and clothing that they are given. In the city there are also located the houses of the families where some of the women work as maids.

Thus, the expressions "leave with the wagon" ${ }^{16 "}$ and "go to the Capital", do not only refer to activities realized in the search for resources, but also to an experience of the city and of the barrio in which trips by and through distinct territories construct different pathways. These pathways create linkages between different and distant social, economic and geographic territories: the north zone of the city of Buenos Aires, characterized by high purchasing power, and the shantytowns located in the Área Reconquista, in San Martín. In the multiple and diverse pathways that the inhabitants of El Salvador traverse daily, they cross these distances and incorporate them

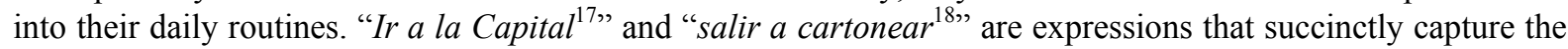
meaning of these pathways, shedding light on the worlds of meaning that intersect within them. The pathway from the province to the Capital is part of the stories of these men and women.

\section{2. "Every Day I Stayed a Little Longer": Nora's Arrival in the Capital}

Nora is one of the women I met during my first year of fieldwork. Her house was a place I went regularly during my visits to El Salvador, and from which point I began to establish contact with other residents of the area. Many times I accompanied her and other women in her family and neighborhood in their "trips ${ }^{19}$ " from the barrio to the city. We walked from her house to the "Suárez $z^{20 "}$ station to take the train that dropped us off in "Carranza".

For many years, Nora has traveled daily by train to the city of Buenos Aires to go scavenging, collecting different types of recyclable materials. In the streets of the city, many doorkeepers, businesses, and neighbors kept papers, cardboard, plastic bottles and other unused household items, like clothing, for her. From $7 \mathrm{pm}$ in the evening, she walks along the streets of a residential neighborhood in the city, stopping in a series of buildings

\footnotetext{
${ }^{15}$ To leave the neighborhood and go scavenging.

${ }^{16}$ Salir con la carreta.

${ }^{17}$ Go to the Capital.

${ }^{18}$ To leave the neigbourhood and go scavenging.

${ }^{19}$ The native expression in spanish is "Salidas".

${ }^{20}$ Its the way in which the inhabitants refers to Jose Leon Suarez.
} 
and businesses where they know her and wait for her to arrive to give her the items they have set aside for her. From Sunday to Friday between $7 \mathrm{pm}$ and 10:30 pm at night, she walks the Palermo neighborhood; Nora tells me, "it's tradition, do you know how many years I have been coming here?" In effect, over the course of time making this daily trip to the Capital, it has become more than a routine. However, this trip was not always made in the same way - that is, the time of day, the way of traveling, even her activities on the streets of the city have changed all along the years. Even so, her pathways between Suárez and the Capital appear to have intertwined with her life story.

Nora is from Tucumán, but for the last fifteen years has lived in Buenos Aires, in El Salvador, together with her partner Luis, and three of their five children: Lisa, 13; Lali, 10; and Seba, 11. At first, she only went to the City of Buenos Aires to visit her older sisters, Ramona and Juana, who had left Tucumán and resettled in José León Suárez. For two years, Nora went back and forth between Tucumán and Buenos Aires; her travels were a time to explore, enjoy herself, and rest. In Tucumán she lived with her mother, her sister Chichi, and the twins, Sol and Juan. These two are her eldest children whom she had when she was twenty years old; when she went to Buenos Aires, they "stayed with" her mother and sister, who raised them as if they were their own. ${ }^{21}$ Of the five sisters, only Chichi still lives in Tucumán, in the house that belonged to their parents. Meanwhile, Nora, Pedro, Ramona, and Juana live in Barrio El Salvador, where they moved and raised their own families next door to one another. Her father was a mason and her mother a housewife; both have passed away. The four girls went to school - Nora says that her mother insisted that they study, although Pedro, the only boy, never started because he preferred to work. Soon after her father died, her mother got sick, and all the siblings had to work to help out at home. For Nora, this meant leaving school in her third year of high school, at which point she began working as an assistant to a Council member legislator in the municipality. During those years, her sisters and brother went to live in Buenos Aires; when her mother died, Nora moved to be with her siblings.

However, this trip was not the final move for Nora. During her stay she met a young man in the neighborhood where her sister lived. They dated for a while; when Nora realized she was pregnant, she decided to return to Tucumán to give birth to her daughter Lisa. A few months later Nora began arranging her return to Buenos Aires, this time to stay. She and Luís ${ }^{22}$ became a couple, and began to build their house on a plot of land next to where he had lived with the children of his former marriage, in a part of the barrio also known as Curita.

\subsection{From Begging to Leave with the Wagon}

A few months after the move, Nora and Luis became the guardians of his children because their mother had abandoned them. In that time, Luis worked as a mason and Nora stayed home taking care of the children. However, when Luis lost his job, Nora began to travel to the Capital, to beg. Things were very bad at that time; "we didn't have anything," she remembers. "To go to the Capital" enabled her to get some food and sometimes clothing that people gave her. Every day she walked to the José León Suárez station, where she took the train to the Ministro Carranza, where she spent almost all day begging. "At the beginning I went to beg," she told me, going to the supermarkets and businesses where they gave her "good food", sometimes clothing, things for the children, with that "she made ends meet." From that first trip to the city, she never stopped going out with the wagon, even during her pregnancies. During that early stage, fourteen years ago, she carried everything they gave her in bags; she didn't carry paper or cardboard, just food, clothing, electronics, and if she was lucky, money. Even when her partner found work or odd jobs to do, she kept going, to help building the house. Once she also tried working as a live-out domestic worker, but a few months later she returned to the Capital; as a maid she was paid very little, 2 or 3 pesos an hour, and with that, "I couldn't do anything".

Over time she began to use a shopping cart to go to the city, so she could carry more and larger items. Later her partner made her a wagon, very similar to those that her neighbors that went to the Capital had begun to make: two iron pipes ended in a wooden fence or an old refrigerator, supported on two wheels, and a nylon canvas on the platform, such as those used in construction for loading sand. A wagon can carry up to one

\footnotetext{
${ }^{21}$ In her investigation of popular Brazilian groups, Fonseca [3] focuses on the circulation of children "a family practice for generations in which children move between the houses of their grandparents, godmothers, neighbors and 'real fathers". Children wind up having various mothers without going through any legal process of adoption. Fonseca's work is relevant to understanding the family dynamics within low-income groups; through the lens of Fonseca's work, Nora's family dynamic began to acquire a new significance in the analysis. In the daily pattern of relationships this fact became central to understanding some of the arrangements that Nora had with her sisters, and also for identifying the specific support and alliances that manifested themselves in the face of distinct family conflicts.

${ }^{22}$ Like many couples I met in the barrio, Luis and Nora never married; Nora says they are "united" ["juntados"].
} 
hundred kilos, or even more, and even with this weight, it is easier to handle than a cart. For this reason, the people who went to the city rapidly adopted it.

Nora continues going to Capital, getting off at the Carranza station of the Mitre line in Palermo, where she has her route. But she no longer begs; now that "I have taken up the wagon, I'm never letting go," she declared.

Nora remembers that in the beginning many went to the city looking for "something to eat", but with time, the demand for cardboard, paper, and other recyclables rose, repositories and places to sell these materials multiplied, and more residents joined the group of those who traveled to the Capital.

\subsection{The Women Go to the City}

Mabel is Nora's neighbor and has been going to Capital to cartonear since 1999. In a conversation we had in front of the train tracks at the Colegiales station, she told me that she previously had walked those same blocks where she now's scavenge "asking for food." when she walked the same blocks of "Belgrano R" to beg. Later, "con esfuerzo" [with effort], she bought a wagon.

In her 60 years, Mabel has had various occupations in different places. She moved to El Salvador eighteen years ago, when she returned from Paraguay where she lived for three months. Her ex-husband had secured a job as a mason there, and they went together, but Mabel couldn't stand it and returned to Buenos Aires alone. Her parents are Paraguayans, but she was born and raised in Argentina. From a young age she worked, always to "help" at home. She held a series of cleaning jobs, first at a computer business, then at a bank, in a geriatric facility, and finally at a local hospital. She was there ten years, until she got sick and was fired. Her daughter was alone and her grandchildren were little, and since Mabel didn't have anything, "got a little wagon" and headed out. It was not the first time that she did so-whenever she had been in between jobs before, she would go to the Capital. But at that time she did not go with a wagon; whatever she found she just carried in bags on her shoulders. Two years ago she separated from her husband and began living with a friend. Her ex-husband, daughter, and two grandchildren stayed in her house, but it is Mabel who "supports" the household. Her ex-husband is sick and cannot do physical work; he is an official mason, and once in a while he does odd jobs or goes to the quema. She goes to the Capital alone, except when her children insist on accompanying her and she reluctantly brings them.

Silvia lives in the adjacent barrio, La Esperanza. Before "going to the Capital," she stayed at home, caring for her children. "I always stayed at home, I never worked, I never went out on the street, nothing," she told me. When her husband el Flaco was without work, a neighbor invited her to go with her to beg. Silvia saw that her neighbor, whose husband also did not work, brought lots of things back with her from the Capital, and decided to try it herself. Her neighbor helped her during her first trips to the city, showing her where they would give her certain things, teaching her the streets. In the beginning she went out with hand-driven carts "changuitos" 23 and brought her children with her. In the bakeries and businesses they give to the little ones but not to those who are older, she explained. Until the wagon appeared, her trips were a means of acquiring daily stuff. Silvia has five children, the oldest being 18 and the youngest 11. She was born in Buenos Aires, but has been living in José León Suárez, in La Esperanza for the last six years, since her parents moved from Villa Martelli to the barrio. There she met her husband (el Flaco), with whom she has been with since she became pregnant with her first daughter at the age of 16. Since 2000, Silvia and el Flaco go out every day with a wagon, accompanied by their eldest daughter and sometimes one of the younger ones. From Suárez to Palermo, in the city of Buenos Aires, the trip by train is part of their routine.

\section{5. "De acá para allá", Luís' Diverse Occupations}

Nora's husband does not go out with the wagon. He went twice with his wife, but quickly stopped. Nora laughs when she remembers the few times he went with her; he didn't know how to work the wagon or carry things, and got tired easily. "He wasn't good at this," she concluded. But although he does not go out to cartonear, he learned to fix the wagons.

Luis has lived in El Salvador since the first houses were built there. He arrived when he was 10 years old, when his family moved from the city of Santa Fe to the house of his sister in one of the older sections of the neighborhood. When he married, he and his wife moved into a new place on the Curita side, close to his and

\footnotetext{
${ }^{23}$ Colloquial expression for supermarket carts.
} 
Nora's present house. He himself told me, "I've always done a little bit of everything". His first job was in a candy shop, where the Avenida Márquez bridge in Suárez now passes. At the age of 12, together with a group of friends, he worked as a stocker for a fruit and vegetable market in the city of Buenos Aires, which alternated locations between the barrios of Urquiza, Villa Pueyrredón and Chacarita. There he was a stocker of various items, carrying and unloading merchandise. He worked in the market for eight years, until it was closed under the military dictatorship. At 16, he started working for a plastic toy manufacturing company recommended by a friend. But that only lasted fifteen days, because "I can't work inside". In fact, all his life he has worked on his own. He learned masonry and had small construction jobs. For six years, he worked with a contractor building sheds in different places around the country. Even when he had a formal employer, he recalls that these jobs "were never in the same place"; once one shed was done, the workers moved to a new location. A work accident prevented him from continuing in this job, since it required a lot of physical exertion. For one year, he was "stuck", receiving unemployment insurance until it ran out and he was granted a license to be a street vendor. He also did paint jobs together with his "compadre" 24 and with the money he saved he bought a truck, one of several vehicles that he eventually bought and sold. With the truck he distributed merchandise in the barrio, bought and sold scrap metal and other wreckage materials. These activities required him to move constantly, both inside and outside the barrio. Thus, he tells me proudly that he "knows everyone", not just in Curita and El Salvador, but other barrios as well, in Suárez and even the Capital. As he explains, he has always hustle, and if he didn't have work, "he invented it".

When I met him in 2004, Luís still had a truck that he used to haul things, and every so often he got an old car that he fixed up in order to sell. His tales about these experiences are full of enthusiasm, which disappears when he refers to his current work as a mason for a construction company. That is why he's saving to buy another truck to replace the one he recently sold to go back to selling and delivery. As he says, he's not made for being inside, or doing the same thing all the time.

\subsection{Learning to "Support Oneself" with the Wagon}

Sandra has been journeying to the Capital since she was 15 , when she arrived from Tucumán. She is 31 years old, with long straight jet black hair that she wears in a ponytail. She has black eyes, and talks and laughs constantly, especially about her children. Her partner is Nora's nephew, Sergio, and together they have two boys, a 3 -year-old (Facundo), and a 1-year-old baby (Leo). Almost every day in the morning, she brings Facundo to Nora's house "they've practically raised him, and he loves it there," she says. Facundo and Leo are not her only children - she has five others, but with a previous partner. She had her first daughter at 18; "I started young", she told me the day we met.

Sandra was born in Tucumán, but between the ages of 5 - 8 she lived with her parents in Zarate, a province of Buenos Aires, until they separated. She and her mother returned to Tucumán, while her four older brothers stayed with her father. Her mother found a new partner and had three more children. Sandra grew up with them and her stepfather, who she describes as "the father who raised me." In their house, "there was never anything extra", her mother went out with a cart and Sandra, as a young girl, went with her. But when she turned 13, she began to work for another family as a maid. Every day she went to school in the morning and worked in the afternoon. At 15 her mother threw her a party and gave her a trip to Buenos Aires because Sandra wanted to go visit the city. She and her three younger brothers came to barrio El Salvador, where they moved in with one of her older brothers and his wife. Sandra doesn't remember this period very well; what comes to mind is her brother demanding that she find a job to "pay for herself" and the mistreatment her brother and sister-in-law inflected her. Her first trips to the Capital were during this time; she was too young for anyone to give her a job, she explained, so she and her younger brothers traveled by train to the city to beg and scavenge. After a year and a half in Buenos Aires, she met her first partner, left her brother's house, and went to live with him. They built a house behind her mother-in-law's "because he didn't want to go far away." "Things went well" for the first few years, but when her first daughter was born, "everything changed". There were not enough diapers, milk...her partner did not work. Sandra remembers "I left to beg at Retiro", to ask the people for help, I walked Retiro...I left at 7 in the morning, and came back at 6 in the afternoon. All day long I was out with the baby...on and on...I

\footnotetext{
${ }^{24}$ Godfather of...

${ }^{25}$ One of Buenos Aires' neighboourhoods located near the downtown. It is known because of its elegant residences, and for being one of the more wealthy neigbourhoods in the city.
} 
finished the house, I have bought everything." Her partner at that time "did not help me; he was a mamma's boy." In different conversations with Sandra, time and again she remarked that she was the one who had "furnished the house with the things I got" in the city, because she knew "how to take care of herself." After their separation, her children remained in the house of her partner, and Sandra temporarily went back to live with her older brother. However, she was the one who continued to take care of the children because her ex-partner was still not working. This situation continued when her ex-partner died, even though the children lived with their grandmother Sandra sent them every month the money she got from the $\operatorname{plan}^{26}$. She assures that all she does is for her children, and continues to go out with the wagon. However, it has made a difference in her present situation; "now it's different", because her current partner, Sergio, helps her a lot. He is a mason, and when he doesn't have a project, he also goes to the Capital. Also from Tucumán, Sergio arrived in Buenos Aires at age 20 and lived with his aunts in El Salvador until he met Sandra. In the beginning he went out with his aunt Juana, helping her to carry things with the wagon, and splitting what they made. Later, when she stopped going, he began to use the wagon and followed the same route, and with what he got through the sale of whatever he got, he helped in his aunt's house. In 2005, when he got back into construction work in Buenos Aires, he found work as a mason, and alternated between that and the wagon. At the end of 2006, one of his employers got a contract in Mar del Plata and Sergio went there to work for five months. During this time, he traveled to Buenos Aires every fifteen days, if they paid him, since as an employee, until he began to work legally they paid him weekly and sometimes he couldn't afford the trip. In March, when his second child was born, he left his job in Mar del Plata and took up the wagon again. Since then, he alternated between various odd jobs in construction and collecting items in the city with Sandra.

\section{7. "Leaving the Wagon"}

Juana, Norma's oldest sister, feels relieved now that she has stopped going out with the wagon. Two years ago she opened a kiosk in the front window of her house, separated from the street by iron grating. Her house is across the street from Nora's and I met her during one of my visits towards the beginning of 2004. At that time, Juana still went to the Capital, although she had difficulties pushing the wagon due to pain in her abdomen aggravated by rheumatism. She was the first of Norma's siblings to leave Tucumán and move to Buenos Aires 26 years ago, where she arrived with her oldest son who was 4 years old at the time. First she worked in a geriatric ward as a nursing assistant; later she worked by the hour as a maid in the Urquiza neighborhood in Buenos Aires. She would go three times a week, but when the family moved, she began to work as a live-in domestic worker At that time, since there was no one to help her with her 8 year old son, she "sent" him to Tucumán so his own mother would take care of him. ${ }^{27}$ After a few years she was able to buy herself a small house on the land that is now Curita, and her son returned to live with her. She took on a partner and had four more children, three boys and one girl. The youngest, Brisa, was born in 2001, and at that time Juana was working as a house cleaner, but her employer called her less and less until she could no longer pay her and Juana was left jobless. The problems with her husband ended in a separation, immediately following the birth of her daughter. Faced with this situation, Juana says that she decided to go out with the wagon. Her sister-in-law Eva and Nora "took" her to the city for the first time and helped her to get to know the Capital, because according to her, she didn't know anything, ${ }^{28}$ although this was not the first time she had left the barrio to go to the city. In her narrative, Juana describes her discomfort with the wagon on the way to the Capital:

"At first I went out with the little supermarket cart, but I hurt myself many times, flipped over... and the police told me they were going to take away the cart. And I didn't go there anymore [referring to station 3 de febrero], now I get off at Carranza and walk to Palermo" (June 2004).

Juana had visited the Palermo neighborhood before, when she and her husband took their children to the zoo. However, going out with the wagon implies knowing the city in a different way, a distinct form of relating one-

\footnotetext{
${ }^{26}$ This is a reference to the Head of Household Program implemented by the national government in 2002. This "plan" consisted of stipends (less than the minimum wage) for unemployed workers over 18 years of age who were "heads of household". In exchange for this subsidy, recipients were required to complete hours of service in public and community organizations or with NGOs.

${ }^{27}$ Here we see how the "circulation" of children between their parents' and grandparents' houses is a common practice of these families. These families' ways of organizing crystallize in these examples giving shape to the alternatives mentioned earlier. These dynamics are not isolated from the other daily practices of these agents. The salida con la carreta articulates itself not simply as a "survival strategy" but as a practice that is present in daily interchanges.

${ }^{28} \mathrm{On}$ this point it is interesting to observe how Juana narrates her experience in the city.
} 
self to this social space. Thus, for Juana, it was necessary that her sister-in-law and her sister went with her to show her a specific use of the city, collecting things.

Since their separation, Juana sleeps in a little room that she built in the back of the house where her ex-husband still lives with four of their five children. During the day, she stays home, cooking and taking care of the kids, and at night she sleeps in this little cement block room that holds only a small bed. In the morning, in addition to cleaning the house, taking the kids to school, and cooking, she distributes the milk as part of "Plan Vida" ${ }^{29}$. Juana has been a "manzanera" ${ }^{, 30}$ for seven years. Every week the local government delivers food (milk, sugar, polenta, rice, and flour) to her for families who have children under age five and pregnant women. The women come to pick up their items from volunteers like Juana. At the same time, three mornings a week, she "works in the plan",31, along with a group of women who make small decorative items that they sell in a market in San Martín.

For four years she went to the Capital with the wagon, where she took on the route left to her by her sister-in-law when she found work as a maid. Finally in 2006 she could "leave the wagon," she told me proudly when I ran into her again at the end of the year. Going to Capital was physically exhausting, and when the wagon was very full, it would tip over. With the kiosk she did not need to leave, she explained; however, she added, she would like to work, do something else like care for the elderly, clean houses, or cook, because "it's hard to be trapped in the house all the time."

She was not the only one who talked about the physical tiredness caused by the wagon, but in Juana's case, the pain she experienced prevented her from continuing to collect enough items to make it financially worthwhile. Her body's condition became an obstacle that made it impossible for her to handle the wagon, reducing the amount of material she could collect and later sell. Even when many people gave her clothes, food, and other items, going out became more and more physically difficult. Thus, the kiosk became a less strenuous option for a woman like her. However, for Juana, staying at home all the time led to another form of exhaustion. Having been able to "leave the wagon," what she wanted to do now was "leave her house."

\section{Some Final Ideas to Open New Debates}

The diverse pathways reconstructed in these pages illuminate a crucial aspect of the way of life of those dedicated to the collection of recyclable materials. The place of these brief histories in the life project of the families studied here cannot be understood without being situated in the symbolic web of the familial group that defines them in a particular way. Boundaries between individual and family projects become blurred, which forces us to turn our eyes to the broader family ties that define them.

The continuities and discontinuities in these pathways reflect the completion of a series of moral obligations tightly linked to the social role of the agent in the group. If from the perspective of the salaried society it appears to be a personal project, the discontinuities and interruptions of these trajectories demonstrate that for these families, the search for resources is part of a web of reciprocation that sustain and nurture such practices, which also give these practices legitimacy.

Men and women use the wagon as one option within the realm of possibilities. As I tried to show in these pages, this option transcends arguments calling it the "last resource" for those "with nothing". The pathways reconstructed her show that "la carreta" the wagon, is present through the lives of the inhabitants of El Salvador. The pathways do not imply a "career" (in professional terms) - rather, the alternation between the salida and other odd jobs creates a dynamic model in which "progress" is not tied to a sense of fulfillment at work. Hierarchies are not established according to the type of work that can be accessed. No job is better than another; there are simply different ways to make a living. The distinction is between those who "do something" and those who don't. In this sense, the hierarchies are linked to what one does with their work-help the family, provide for the household, or slack off. Thus certain values associated with work (as a singular historical construction) continue to affect the criteria for social prestige within the group. However, this is not a logic of work or of provision [19], one prevailing over the other, but has to do with the unique histories that conceptions of work are part of.

\footnotetext{
${ }^{29}$ This is the maternal-infant program of the provincial government of Buenos Aires for pregnant or nursing women, or women whose children have not yet enrolled in primary school.

${ }^{30}$ Manzaneras are delegates of the local assistance program "Más Vida" (also known as "Plan Vida"), originally created during the government of Eduardo Duhalde in the province of Buenos Aires in 1994.

${ }^{31}$ This refers to the Head of Household Program (Plan Jefas y Jefes de Hogar).
} 
In the horizon of meanings for Sandra, work appears linked to the possibility of "providing for her children," giving them a roof and food, and "being able to sustain herself alone." In her story, we see how from a young age she saw the street as a place of provision, but not where one goes to "hunt," following the metaphor employed by Merklen [20], but rather as a place where she can meet her obligations as a mother and play the role that her ex-husband left vacant by abandoning his role as father.

In this way, the salida sustains the morality of the group, operating as a mechanism that defines acceptable forms of social prestige among men and women.

\section{References}

[1] Gorbán, D. (2005) Formas de Organización y Espacio. Reflexiones Alrededor del Caso de los Trabajadores Cartoneros de José León Suárez. Master Thesis in Social Science Research, Buenos Aires University, Buenos Aires.

[2] Gorbán, D. (2009) La Construcción Social del Espacio y la Movilización Colectiva. Las Formas de Organización Espacial de los Sectores Populares en Buenos Aires. Ph.D. Thesis, Buenos Aires University/Ecole des Hautes Etudes en Sciences Sociales, Buenos Aires, 2009.

[3] Fonseca, C. (1995) Caminos de Adopción. Buenos Aires, Eudeba.

[4] Gentile, F. (2008) Ser Niño o Niña y Estar en la Calle: Género y Sociabilidad. In: Pojomovsky, Julieta, Cruzar la Calle, Eds., Vínculos con las Instituciones y Relaciones de Género Entre Niños, Niñas y Adolescentes en Situación de Calle, Vol. 2, Espacio Editors, Buenos Aires.

[5] Gowan, T. (2009) New Hobos or Neo-Romantic Fantasy? Urban Ethnography beyond the Neoliberal Disconnect. Qualitative Sociology, 32, Springer Netherlands Editor.

[6] Magni, C.T. (2006) Nomadismo Urbano: Uma Etnografía Sobre Moradores de rua em Porto Alegre. EDUNISC Editors, Santa Cruz do Sul.

[7] Schorr, M. (2004) Industria y Nación. Poder Económico, Neoliberalismo y Alternativas de Reindustrialización en la Argentina Contemporánea. Edharsa Editors, Buenos Aires.

[8] Maristella, S., Ed. (2000) Desde Abajo. La Transformación de las Identidades Sociales. Biblos-UNGS Editors, Buenos Aires.

[9] Fonseca, C. (2004) Familia, Fofoca e Honra. Etnografía de Relaçoes de Gênero e Violencia em Grupos Populares. 2nd Edition, UFGRS Editor, Porto Alegre.

[10] Merklen, D. (1991) Asentamientos en La Matanza. La Terquedad de lo Nuestro. Catálogo Editors, Buenos Aires.

[11] Azpiazu, D. and Schorr, M. (2002) Privatizaciones, Rentas de Privilegio, Subordinación Estatal y Acumulación del Capital en la Argentina Contemporánea. FLACSO, Latin American Faculty of Social Sciences, Argentina.

[12] Basualdo, E. (2001) Sistema Político y Modelo de Acumulación en la Argentina. Notas Sobre el Transformismo Argentino Durante la Valorización Financiera (1976-2001). FLACSO/Quilmes National University/IDEP.

[13] Battistini, O. (2004) Un Modelo Cultural en una Argentina Siempre en Crisis. In: Boyer, R. and Neffa, J.C., Eds., La Economía Argentina y su Crisis (1976-2001): Visiones Institucionalistas y Regulacionistas, Miño \& Dávila Editorial, Co-Edited between Ceil-Piette \& the Institut CDC pour la Recherche, Buenos Aires.

[14] Altimir, O. and Beccaria, L. (1999) El Mercado de Trabajo Bajo el Nuevo Régimen Económico en Argentina. In Series Reformas Económicas No. 28, United Nations/CEALS, Santiago de Chile.

[15] Salvia, A. (2003) Mercados Segmentados en la Argentina 1991-2002. Lavboratorio. Report in Labor Actuality, Social Sciences Faculty, Buenos Aires University, Buenos Aires.

[16] Salvia, A. (2004) Crisis del Empleo y Nueva Marginalidad en la Argentina. En Argumentos, Revista Electrónica de Crítica Social, No. 4, The Gino Germani Research Institute, Social Sciences Faculty, Buenos Aires University.

[17] Battistini, O. (2002) La Atmósfera Incandescente. Escritos Políticos Sobre la Argentina Movilizada. Asociación Trabajo y Sociedad, Buenos Aires.

[18] Schuster, F., et al. (2005) La Trama de la Crisis. La Protesta Social en la Argentina 2001. Prometeo Editors, Buenos Aires.

[19] Kessler, G. (2002) De Proveedores, Vecinos y Barderos. In: Silvio, F. and Miguel, M. Eds., Sociedad y Sociabilidad en la Argentina de los 90, Buenos Aires.

[20] Merklen, D. (2005) Pobres Ciudadanos. Las Clases Populares en la era Democrática (Argentina, 1983-2003). Gorla Editors, Buenos Aires. 